\title{
Choosing Between Online and Face-to-Face Courses: Community College Student Voices
}

\author{
Shanna Smith Jaggars \\ Teachers College, Columbia University
}

\begin{abstract}
In this study, community college students discussed their experiences with online and face-to-face learning as well as their reasons for selecting online (rather than face to face) sections of specific courses. Students reported lower levels of instructor presence in online courses and that they needed to "teach themselves." Accordingly, most students preferred to take only "easy" academic subjects online; they preferred to take "difficult" or "important" subjects face to face. To meet students' needs, then, colleges need to either more explicitly build instructor presence and guidance into online courses or continue to provide ample face-to-face sections of courses for those students who prefer them.
\end{abstract}

This is an Author's Accepted Manuscript of an article published in the American Journal of Distance Education, Volume 28, Issue 1, available online: http://www.tandfonline.com/doi/abs/10.1080/08923647.2014.867697 
While nearly half of community college students have taken at least one fully online course, most enroll in only one or two online courses each semester, filling the rest of their schedule with face-to-face courses (Jaggars 2012; Public Agenda 2013). It is not clear, however, whether students prefer this "mix-and-match" strategy, or whether they would prefer to take all their courses online and are simply thwarted by a lack of available offerings. In order to scale online learning offerings appropriately, community college administrators need a stronger understanding of the reasons students take some courses online and others face to face.

Several previous studies have established that convenience and flexibility are key factors that entice students to enroll in online coursework (Aslanian and Clinefelter 2013; Benbunan-Fich and Hiltz 2003; Farris, Haskins, and Yemen 2003; Hittelman 2001; Flowers and Cotton 2003; Kariya 2003; Noel-Levitz 2006). In contrast, few students choose an online course because they believe it will provide a superior learning experience (Farris, Haskins, and Yemen 2003; Aslanian and Clinefelter 2013; Public Agenda 2013). For example, in a recent survey of community college students, only $3 \%$ believed that students learn more in an online-only class than in a face-to-face class (Public Agenda 2013).

Students may also be dissuaded from online learning if they or a peer have had a negative academic experience with an online course. Negative experiences can arise from technical problems (Bambara et al. 2009; El Mansour and Mupinga 2007; Hara and Kling 1999; Mupinga, Nora, and Yaw 2006; Navarro and Shoemaker 2000; 
Rivera, McAlister, and Rice 2002; Wang 2008; Zavarella 2008), a reduced sense of instructor and peer presence (Bambara et al. 2009; El Mansour and Mupinga 2007), or difficulties handling the degree of time-management and self-directed learning required by many online courses (Bork and Rucks-Ahidiana 2013; Yen and Liu 2009). Perhaps due to such factors, community college students tend to perform more poorly in online than in face-to-face courses (for a review, see Jaggars 2012; also see Kaupp 2012; Xu and Jaggars, in press).

As of yet, no studies have examined how students balance a desire for flexibility against potential concerns about academic performance as they consider whether to take courses online or face to face. The literature is also silent on whether the particular course subject under consideration-for example, English or biology—influences students' decision-making processes. This article draws on findings from a qualitative study at two community colleges to explore the factors that students consider as they choose between online and face-to-face offerings.

\section{METHOD}

The data discussed in this article are drawn from a larger study of online learning (also see Barragan and Rucks-Ahidiana 2013; Jaggars and Xu 2013). In spring 2011, the research team collected data at two Virginia community colleges, with a particular focus on high-demand introductory courses (such as English, math, sociology, and biology) that offered sections in a fully online format. The team conducted interviews with online faculty, support and administrative staff, and 47 
students who were taking at least one online course in that semester. This analysis focuses on the student interview portion of the study. Student respondents were primarily African American or White (reflecting the ethnic makeup of the colleges), and approximately half appeared to be aged 30 or older. Most were attending college full time while also working. Three-quarters had taken an online course in a prior semester, and most reported that they expected to pass their current online course(s).

Semistructured interview protocols focused on experiences and perceptions related to online learning, particularly on the students' learning experiences in their current online courses. Students were also asked to report why they chose to take each of their current courses in an online setting. Interviews were recorded and transcribed. For the current analysis, the author developed a preliminary set of codes based on impressions from the interviews in terms of students' reasons for selecting online or face-to-face course sections, including life demands or responsibilities, structural barriers (such as lack of transportation), learning style preferences, interaction with instructors, and interaction with other students. After coding a small set of test transcripts, the codes were slightly refined and expanded. After all transcripts were coded, the final set of codes was organized according to the larger thematic areas laid out in the next section. Quotes included in the next section are presented verbatim, with the occasional excision of verbal fillers (for example, "um" or "you know") when they did not add meaning. 


\section{FINDINGS}

Overall, respondents provided several general reasons to choose online coursework, discussed in more detail below. As expected based on the previous literature, flexibility and convenience were key reasons to take courses online; moreover, a handful of students preferred the learning environment of online learning. Despite these advantages, however, very few respondents wished to take all their courses online. In subsequent sections, the author first discusses general reasons students wished to take courses online or face to face, and then how those factors played out as students faced the decision to take particular courses online, rather than face to face.

\section{General Reasons to Choose Online Courses}

Students cited two broad reasons for taking courses online. First, almost all students appreciated the flexibility and convenience of online courses, and some felt that online courses allowed them to use their learning time more efficiently. In addition to these structural reasons, a few students felt that online courses were a better match to their own learning style or interpersonal interaction preferences.

Flexibility, convenience, and time efficiency. When asked why they chose to take online courses, almost all respondents explained that they had busy lives with 
multiple responsibilities and that the flexibility of online learning helped them better balance their schedule. One-third of the sample specifically mentioned childcare responsibilities; as one mother said,

I think one thing that influences a full-time working adult to do distance learning is: how much time are you willing to sacrifice away from your family? ... I just left Algebra II last semester, which was two days a week for two hours at night. That was tough. I missed a lot in my son's school and his sports, so it was more of a personal choice when I came back to register for the spring classes. I said, "You know, I think I'm only willing to sacrifice one night a week for school, for my family."

Over 80 percent of the sample also reported that they were employed. Interviewers did not specifically probe respondents about the nature of their employment, but as students discussed their reasons for choosing online coursework, more than half of those who were employed explained that they worked full time or longer each week. An additional 11 percent volunteered that they worked overnight shifts, and 8 percent mentioned that they had unpredictable schedules, with work shifts that varied from week to week. Several respondents who worked long or variable hours explained that without the option of online course taking, they would enroll in fewer courses each semester. As one student said, 
Unless I only wanted to work part time or quit my job, I felt that [online coursework] was the only way that I was going to get my classes in, unless I wanted to take one or maybe two classes a semester.

Outside of the advantage of flexible scheduling, some students also said that they chose online learning to reduce the number of times they needed to travel to campus. About 20 percent of respondents mentioned transportation issues; most of these involved living a long distance from campus, having no car or sharing a car, or dealing with the price of gasoline. Most respondents also alluded to the comfort of working at home, with several specifically noting that they enjoyed the ability to take breaks, have snacks, work "in your pajamas," or avoid venturing outside during the cold winter months.

In addition to the advantages of flexibility, at-home convenience, and reduced travel time, several students said they preferred online courses because these courses allowed them to use their time more efficiently. These students felt that in-class time was often wasted, sometimes due to the instructor's choices and sometimes due to other students. For example, one student noted:

Really you have more time [in an online course], because you don't have that time where a classmate may come in and disrupt the class, or somebody's not getting it and then you're sitting there having to 
listen and wait until they get it. And I'm sitting there twiddling my fingers going "Okay, are they going to get this thing or what are they doing?"

Another student complained of his face-to-face English instructor: "Nobody has questions, so she keeps talking and talking and she fills up the whole class, instead of letting us go to work on the papers." Students citing such complaints tended to feel that they could learn the material and complete assignments more quickly if they were able to skip the in-class portion of the course. In contrast to this view that online courses were more efficient, however, most other students felt that online courses were more challenging and difficult (for more details, see Bork and Rucks-Ahidiana 2013), and several noted that online courses were more time consuming. As one student said, "I thought that distance learning was less time spent on the work, and it's totally not. If anything you are spending more time on the work, because you have lost that face-to-face interaction." Another student agreed, noting that there was a balance between time saved in class and time spent in extra work: "It was just a lot more than what would have to be done if I was in a class. So I think that's the trade-off as far as that time of sitting in the class." Indeed, of the ten or so students who made comments to the effect that online courses used time more efficiently, about half also noted that they entailed equal or more amounts of work. Thus only a handful of students seemed to feel that online courses provided inherent time savings. 
Learning and interaction preferences. In addition to the structural reasons for choosing online learning, several students cited learning- and interactionoriented factors. Three students explicitly said that they learned course material more effectively in the online context. One explained that the online course materials were "way more valuable than to be sitting in the classroom having someone lecture to me"; the second said, "I just have trouble sitting, being still and listening to somebody for like a long period of time, because I'm kind of ADD. ${ }^{1}$ I can't stay on one track." This student felt that it was "better for me to do it at home, because if I get side-tracked, at least I know I'll come back to it." And the third said that when she worked online,

I'm not so much distracted by other students. ... And I think the professors definitely, I just like the way they taught. So I don't know if [online professors] learn the same way, or teach the same way I learn? I enjoy it a lot.

In contrast, most other students seemed to feel that they learned better in face-toface courses, a theme that is explored in more detail in subsequent sections.

Finally, some students, particularly older students, noted that they tended to prefer online courses due to the lack of face-to-face interaction with other students. As one older student explained:

\footnotetext{
${ }^{1} A D D$ is a common abbreviation of the term attention deficit disorder.
} 
I think a lot of the older, mature people take online classes because they are afraid of the classroom. I was when I first took my first class. I'm like, "I'm the oldest thing in here and these kids just got out of high school. I can't remember all of this stuff." And I think the older person, the mature person, leans toward the online classes basically because of, you know, it's almost like stage fright. I mean being out of school for 20 years and then going back to a classroom, it just kind of scares you. It did me.

A half-dozen students of nontraditional age echoed this theme, with one underlining the fact that

being in a class with a whole bunch of youngsters talking about their weekend, it's kind of like, "I can do without." ...That's why when you're online you're like, "I don't need to interact with them, so I'm not going to."

\section{Why Not Take All Courses Online?}

Overall, despite the fact that most students strongly appreciated the flexibility and at-home accommodation that online learning provides, only five students said that they would take all their courses online if they could. Perhaps not coincidentally, three of these students were the same respondents who said they 
learned better online than in the face-to-face setting, and the fourth was one of the students who felt they could complete coursework significantly more quickly in the online setting. For the fifth student, the overriding benefit of online courses was flexibility, given that she worked full time and was a single parent of two children. Given the clear advantages of online coursework, why did the rest of the sample feel it was important to take at least some courses on campus?

General reasons to take courses face to face. Students provided two general reasons they took at least some courses face to face: (1) to maintain a connection to the campus and their peers and (2) the stronger student-instructor connection.

First, several students implied that it was important to maintain a connection to the physical campus or to other students. A few articulated their distaste for purely online colleges with no campus; one student noted that she simply felt more "comfortable" going to a college with a physical campus: "I feel like I can still take online courses, but still have [the campus] here if I have any questions. I have somewhere to come in person to ask questions or whatever." For others, the importance of the physical campus seemed tied to the importance of a face-to-face connection with other students. Respondents generally agreed that online courses included lower levels of student-student interaction than face-to-face coursesalthough, as might be evident from the preceding discussion on older students, opinions were mixed as to whether this reduced interaction was a positive, negative, or neutral aspect of online learning. For those who valued interactions with other students, however, the limited student interaction in online courses provided a 
reason to take at least some courses face to face. For example, a student who was attending two colleges (taking online and face-to-face courses from the college under study as well as online courses from another college) explained:

I think that being in the specific curriculum that I am, with the oncampus classes, it has given me a stronger tie to the school. I'll be graduating both of these colleges in May, and unfortunately both of their graduations are on the same date, so I had to choose which one I wanted to do. And I chose to come to this school because my peers are here.

Second, almost all students noted that the nature of the student-instructor interaction was more "distant," less "personal," less "immediate," less "detailed," or less "solid" online. In particular, they missed the direct instruction that they received in face-to-face courses, and many felt as though they were "teaching themselves." One student explained,

It just seems more, when you do it online, if you need help, your teacher is basically not there. Like face-to-face, she can help you a little bit more. But then when it comes to online, you have to teach yourself, I guess you could say. 
Other analyses based on the larger study discuss the nature of studentinstructor and student-student interaction in more detail (see Bork and RucksAhidiana 2013; Jaggars and $\mathrm{Xu}$ 2013). In this article, the author focuses on the impact of these weaker interpersonal connections in terms of students' decisions to take a particular course online rather than face to face, as discussed in more detail in the following section.

\section{Reasons to Take Specific Courses Online Rather Than Face to Face}

While students were pulled toward online courses due to their flexibility and convenience (and for some, personal learning preferences), they were also pushed away from online courses due to the weaker instructor presence (and, to a lesser extent, the weaker student-student interaction). Each student had idiosyncratic ways of balancing between these sets of considerations when faced with the choice of whether to take a particular course online or face to face. In some cases there was no choice: A needed course was simply not available face to face at a time when the student could attend, and the student thus found it necessary to enroll in an online section. In most cases, however, students made a conscious decision to enroll in a particular course online, based on three factors specific to the academic subject area: (1) whether the subject area was well suited to the online context, (2) whether the course was "easy" or "difficult," and (3) whether the course was "interesting" and/or "important." 
Suitability of the subject area. The first category of courses students preferred to take face to face was subject areas that they judged to be poorly suited to online learning. Several students mentioned laboratory science courses in this context. While one respondent enthused about the excellence of the at-home chemistry materials provided through her online course, others were not convinced. As one noted, 'It's kind of like, 'No, that seems a bit much.' I don't want to have a chemistry lab going on in my kitchen." Some also preferred not to take science courses online because they classified them under the heading of "difficult" courses, as discussed further in the following section.

Students also tended to agree that foreign language courses were not suitable to online learning. Based on students' explanations, it appeared that language practice in these courses was purely textual, with little opportunity for listening and no opportunity for spoken practice. As one student explained, "When all you do is write your German and type in little prompts, you're not really learning how to speak it." Along similar lines, several students felt that public speaking was inappropriate to take online. Although her college's online public speaking course did provide opportunities for students to perform video-based speeches, one student reported that the video-based speech activities sometimes suffered from technical difficulties and were not sufficient to fully capture the experience of public speaking. She said,

If I really wanted to get something out of the class, I'd want a podium and a live audience. ... I think it would be very good if she did just let 
us get together a couple times to do our speech. It might be hard for some people, so it may be that she needs to make it a hybrid class and say, "These are certain times when you have to come to class to make your speech," whether it's in the middle of a day or at night, like from 6 to 8 or something. That would make me more nervous, [but I would] realize, "well yeah, that's what it's all about." I feel like I'm "getting away with it" a little bit by just talking on the computer, where I can't really see everybody, but they can see me.

Course difficulty. Most students reported that they preferred to take courses online only when they thought the subject area would be easy for them; they preferred to take more difficult courses face to face. For example, 40 percent of the respondents volunteered that they would prefer not to take a math course online because they perceived that it would be too difficult. As one student said, “There's no way I could do algebra online. I'm barely making it through algebra right now, face-to-face, so I know I could not do it online."

When students discussed courses they would avoid taking online due to the difficulty of the subject area, they consistently noted that these were subjects in which they could not "teach themselves." As one student said,

Sometimes I can teach myself something out of the book, and sometimes I can't. It just depends on your strengths. I could never 
teach myself math, it's not my strong point. I would suffer. But I could probably teach myself, I could probably do history and survive.

Although different students found different subject areas easier or harder, for many students it seemed that the words easy and difficult were code words for humanities versus math and science. These respondents tended to provide explanations similar to that of the following student, as she summarized which courses she would take online this semester:

I knew I had to take my math on campus. I knew I couldn't take it online. And I wanted to have as much credits as I could get this semester, so my advisor told me certain classes I could take. And then she said, "Well these are online," and I figured that they are mostly reading. Which they are, health is mostly reading. And college composition, it's reading and writing. I figured I could do those online.

When pressed to explain why they would not take math courses online, students offered explanations such as this one:

Just because with math I would rather be face-to-face. That way I can see what the teacher does, how she does it, and get some more one-on-one help rather than having the material and trying to figure it out for myself. 
Another student explained similarly: "Math, for me personally, I will not get it looking at numbers. I need somebody to stand in front of me and teach me and explain as they go, and let me ask questions."

Few of the sample reported having a strong aptitude for math or science, but those who did used similar reasoning to explain which courses were easy for them; for example, when asked to explain which courses he would be willing to take online, one said, "It could be something easy, like science is just reading and you've got to study. It's not like you have to actually do work. It's just facts and definitions, it's really not hard."

Overall, students thought that they could "teach themselves" courses if they felt competent to learn the subject matter strictly from a textbook or other readings, with little or no explicit instruction. For more difficult courses, they felt that stronger instructor guidance was necessary. For example, one student explained that "if you took a class you were uncomfortable with" online, then "you wouldn't have anything to really base it off of, whereas with a teacher being there next to you could really just break it down for you so much better." Another said,

I think [online] is good for some courses. Other courses, I think I'll need to be in the classroom. You know, sometimes you just don't get it and I think you need that "little extra" instruction, and [you] are able to ask questions right then and there. 
Students felt that in difficult courses, they needed the immediate questionand-answer context of a face-to-face course. As one student said, "It's just easier to talk to them about any issues that you're having face-to-face, rather than emailing somebody who you have no idea who they are, and then waiting for a response, however long it's going to take." Another explained that in online courses,

I think that communication barrier is the hardest one. I think that the difference is, once again, being able to ask questions on the spot. Depending, of course, on the level of the class and what type of learning you are doing in there. If it's a class where you can pretty much go off the book and you're not going to ask a lot of questions, that's fine, online doesn't affect you.

In general for students across the sample, the weaker student-instructor interaction in the online context was a strong argument against taking difficult courses online. Fewer students alluded to student-student interaction when explaining why they avoided taking difficult courses online; this theme arose only a handful of times. But as one student, who said that she would prefer to take English courses face to face, explained:

I guess with English, I'm not really good. I have to read a story probably three or four times before I really grasp what it's about. Where in a classroom you can get different opinions, different ideas, 
and draw a better conclusion yourself; where [online] I didn't really have that. Yeah, you have the peer review board, but it's not the same as being there like you and I are talking right now.

As a final summary of the problems involved with taking a difficult course online, one student explained:

If you're not comfortable learning the material on your own and teaching yourself, then you should be in class. That's the biggest thing, because even with all the handouts, all the notes, you're the only one that's really holding yourself responsible for the material. And if you find that you have a lot of questions or need another person's point of view on a subject, then it's best to be in class. That way you can have your point of view, the teacher's, and all the comments of the students around you to help support your learning. If you don't need that information and you're really able to pick up on general concepts on your own, then I would say definitely be outside of class. Because some things ... I can pick up general concepts and I don't need to be in class. Others, I need to be in class. So each person has to really look at themselves to figure out, "Is this a good subject for me? Is this not a good subject for me? Does this sound like something I can do on my own?" 
Because that's really how it is. Even though you can email the teachers, you're really on your own.

Course importance and interest. In terms of the third category of courses that students were reluctant to take online, several respondents said they preferred to take "important" courses (including courses in their academic major) or "interesting" subjects face to face. For example, one student said that she had initially signed up for a particular course online, "But I started to, I actually enjoyed going, or actually enjoyed the class, so I didn't want to just take it online. I wanted to actually go sit in the classroom and actually learn about it." As these students discussed why they preferred to take such courses face to face, they consistently stressed the importance of instructor presence. For example, a student said she preferred taking psychology courses face to face because "I think I could learn so much more, and those teachers, they always have other little things to talk about in the class, and stories and examples, and you don't really get that quite as much with online."

A few students also added that, in addition to the instructor's presence, the presence of other students was important in these particular courses. One student explained:

The class I'm taking this evening is not offered distance, just because it can't. It's a group therapy class and you've got to be there with other classmates, and you need a teacher. And he relies a lot on his 
day-to-day experiences and relaying them to the class. There would be a lot that would be missed if it were given as a distance class.

Another student, referring to an English literature course, said:

A lit class online almost just seems like a bit of a yawn. I think there's something to being amongst a group of people for that kind of class. ... I have Shakespeare Histories and Comedies, I can't imagine doing that online, because there is so much there to discuss and interpret. And then just to see your teacher's opinion and know your opinion, it seems like a bit of a loss [to take a literature course online].

\section{DISCUSSION AND CONCLUSION}

In weaving together students' perspectives on course-specific and subjectspecific reasons to select online versus face-to-face sections, there seemed to be a strong underlying pattern: Most students suspected they did not learn the course material as well when they took it online. ${ }^{2}$ For most students, this deficit was due to

\footnotetext{
${ }^{2}$ It was not possible to empirically verify whether this particular sample of students indeed performed more poorly in online courses than they would in face-to-face courses. However, their perspectives align with a previous study of introductory math and English courses across all 23 Virginia community colleges which found that, after controlling for a wide array of student characteristics, students were substantially less likely to successfully complete online courses with a $\mathrm{C}$ or better, compared with face-to-face courses (Xu and Jaggars 2011).
} 
reduced teacher explanation and interaction; for some respondents, the weaker student-student interaction was also problematic. As a result, students did not want to risk taking difficult courses online and preferred what they considered to be the richer experience of the face-to-face classroom when learning about subjects they felt were particularly interesting or important.

The findings of the current article suggest that, unless a college works to systematically cultivate strong levels of instructor presence and guidance into its online courses, its students' demand for online learning may soon level off. Moreover, students' online enrollments may tend to concentrate in introductory humanities courses and other subject areas that are generally regarded as "easy"that is, courses that are primarily reading-based and require little hands-on application.

In considering how to apply the results of this article to their institutions, community colleges may wish to survey their online learners in order to understand whether students perceive a gap between the college's online and face-to-face offerings in terms of instructor guidance and presence, or in terms of the quality of learning. If such gaps are observed, college leadership could work closely with both full-time and part-time instructors to identify opportunities and resources for improvement.

The literature on faculty development suggests that top-down approaches to pedagogical improvement-such as one-time required faculty workshops-are unlikely to strongly impact instructors' every day practices (e.g., Edgecombe and Bickerstaff 2012; Guskey and Yoon 2009; Murray 2002; Waskow 2006). Instead, 
colleges could create structures that cultivate and support a bottom-up approach to improvement. For example, college leadership could work with faculty committees to design student survey items that would provide useful and actionable feedback for both online and face-to-face instructors; disaggregate survey data by program or department and share those results with department chairs and program coordinators; encourage the creation of faculty inquiry groups that would generate ideas and provide mutual support for pedagogical improvement; and fund instructional technologists to provide technical input and support for course design and improvement (e.g., see Dietz-Uhler, Fisher, and Han 2007; Grubb and Gabriner 2013; Hixon 2008; Huber 2008; Ice 2009; Marincovich 1998).

Such improvement processes might initially focus on online courses, but they should not dissipate once a college has successfully closed any observed gaps between online and face-to-face sections. While most students in our study preferred to enroll in face-to-face sections for certain courses, that does not necessarily imply that they were always pleased with the quality of learning in their face-to-face courses. Many face-to-face community college courses still revolve around lectures and other instructor-centered approaches and could certainly benefit from pedagogical improvement (Cox 2009; Grubb and Gabriner 2013). Accordingly, colleges may wish to first ground their improvement processes in the relatively innovative culture of online instruction, and after having demonstrated success in that environment, expand those processes across the entire institution.

\section{FUNDING}


This research was funded by the Bill \& Melinda Gates Foundation.

\section{ACKNOWLEDGMENTS}

Members of the research team who contributed to the data collection and coding for

this analysis include Nikki Edgecombe, Melissa Barragan, Rachel Hare Bork, Thao Tran, Zawadi Rucks-Ahidiana, and Di Xu. For more information about the dataset, please contact Shanna S. Jaggars.

\section{REFERENCES}

Aslanian, C. B., and D. L. Clinefelter. 2013. Online college students 2013: Comprehensive data on demands and preferences. Louisville, KY: The Learning House, Inc.

Bambara, C. S., C. P. Harbour, T. G. Davies, and S. Athey. 2009. Delicate engagement: The lived experience of community college students enrolled in high-risk online courses. Community College Review 36 (3): 219-238.

Benbunan-Fich, R., and S. R. Hiltz. 2003. Mediators of the effectiveness of online courses. IEEE Transactions on Professional Communication 46 (4): 298-312.

Bork, R. H., and Z. Rucks-Ahidiana. 2013. Role ambiguity in online courses: An analysis of student and instructor expectations (CCRC Working Paper No. 64). New York: Columbia University, Teachers College, Community College Research Center. 
Cox, R. D. 2009. The college fear factor: How students and professors misunderstand one another. Cambridge, MA: Harvard University Press.

Dietz-Uhler, B., A. Fisher, and A. Han. 2007. Designing online courses to promote student retention. Journal of Educational Technology Systems 36 (1): 105-112.

Edgecombe, N., and S. Bickerstaff. 2012. Pathways to faculty learning and pedagogical improvement (Inside Out No. 3). New York: Columbia University, Teachers College, Community College Research Center.

El Mansour, B., and D. M. Mupinga. 2007. Students' positive and negative experiences in hybrid and online classes. College Student Journal 41 (1): 242-248.

Farris, P. W., M. E. Haskins, and G. Yemen. 2003. Executive education programs go back to school. Journal of Management Development 22 (9/10): 784-802.

Flowers, J., and S. Cotton. 2003. Master of arts in career and technical education-now 100\% online. Tech Directions 63 (2): 22-23.

Grubb, W. N., and R. Gabriner. 2013. Basic skills education in community colleges: Inside and outside of classrooms. New York: Routledge.

Guskey, T. R., and K. S. Yoon. 2009. What works in professional development? The Phi Delta Kappan 90 (7): 495-500.

Hara, N., and R. Kling. 1999. Students' frustrations with a web-based distance education course. First Monday 4 (12). Available online at http://firstmonday.org/article/view/710/620

Hittelman, M. 2001. Distance education report, August 2001: California community colleges, fiscal years 1995-1996 through 1999-2000. Sacramento, CA: California Community Colleges, Office of the Chancellor. 
Hixon, E. 2008. Team-based online course development: A case study of collaboration models. Online Journal of Distance Learning Administration 11 (4). Available online at http://www.westga.edu/ distance/ojdla/

Huber, M. T. 2008. The promise of faculty inquiry for teaching and learning basic skills. Stanford, CA: Carnegie Foundation for the Advancement of Teaching.

Ice, P. 2009. Using the Community of Inquiry Framework survey for multi-level institutional evaluation and continuous quality improvement. The Sloan Consortium. Available online at http://sloanconsortium.org/

Jaggars, S. S. 2012. Online learning in community colleges. In Handbook of Distance Education, 3rd ed., ed. M. G. Moore, 594-608. New York: Routledge.

Jaggars, S. S., and D. Xu. 2013. Predicting online student outcomes from a measure of course quality (CCRC Working Paper No. 57). New York: Columbia University, Teachers College, Community College Research Center.

Kariya, S. 2003. Online education expands and evolves. IEEE Spectrum 40 (5): 49-51.

Kaupp, R. 2012. Online penalty: The impact of online instruction on the Latino-White achievement gap. Journal of Applied Research in the Community College 12 (2): 1-9.

Marincovich, M. 1998. Ending the disconnect between the student evaluation of teaching and the improvement of teaching: A faculty developer's plea. Stanford, CA: National Center for Postsecondary Improvement.

Mupinga, D. M., R. T. Nora, and D. C. Yaw. 2006. The learning styles, expectations, and needs of online students. College Teaching 54 (1): 185-189.

Murray, J. P. 2002. The current state of faculty development in two-year colleges. New Directions for Community Colleges 2002 (118): 89-98.

Navarro, P., and J. Shoemaker. 2000. Performance and perceptions of distance learners in cyberspace. The American Journal of Distance Education 14 (2): 15-35. 
Noel-Levitz. 2006. National online learners priorities report. Available online at https://www.noellevitz.com/upload/Papers_and_Research/2006/060NLINE_repor t.pdf

Public Agenda 2013. What employers and community college students think about online education. Available online at http://www.publicagenda.org/pages/not-yet-sold

Rivera, J. C., M. K. McAlister, and M. L. Rice. 2002. A comparison of student outcomes and satisfaction between traditional and web based course offerings. Online Journal of Distance Learning Administration 5 (3): 151-179.

Wang, L. 2008. Developing and evaluating an interactive multimedia instructional tool: Learning outcomes and user experiences of optometry students. Journal of Educational Multimedia and Hypermedia, 17(1), 43-57.

Waskow, J. A. 2006. Understanding and application of learner-centeredness among community college faculty. Ph.D. diss., Walden University, Minneapolis, MN.

$\mathrm{Xu}$, D., and S. S. Jaggars. 2011. The effectiveness of distance education across Virginia's Community Colleges: Evidence from introductory college-level math and English courses. Educational Evaluation and Policy Analysis 33 (3): 360-377.

- - - In press. Performance gaps between online and face-to-face courses: Differences across types of students and academic subject areas. Forthcoming in the Journal of Higher Education.

Yen, H. J., and S. Liu. 2009. Learner autonomy as a predictor of course success and final grades in community college online courses. Journal of Educational Computing Research 41 (3): 347-367.

Zavarella, C. A. 2008. Computer-based instruction and remedial mathematics: A study of student retention at a Florida community college. Ph.D. diss., University of South Florida, Tampa. 
